\title{
Mångfald, klass och ojämlikhet
}

\author{
Göran Therborn
}

Den här boken är ett "mångfaldsarbete", för att återanvända ett begrepp från ett av kapitlen (Holgersson och Romani), ett begrepp med ursprung i den relativt upplysta delen av det amerikanska affärslivet, där det kallas diversity management. Sammantagna ger bokens bidrag en fascinerande bild av arbetsplatsers sociala mångfald, inte bara i Sverige utan också för Volvoarbetare i Mexiko och Sydafrika och för vårdarbetare i London, Madrid och Paris. Utan att dra ihop de många trådarna till några sammanfattande analytiska slutsatser ger bokens mångfaldsarbete ett viktigt bidrag till att vidga läsarens syn på arbete, arbetsplatser och arbetsförhållanden.

Den inspirerar också till vidare reflexioner om klass och ojämlikhet. Arbetsplatser i ett kapitalistiskt samhälle som det svenska är där klasser konfronteras med varandra. Det som är ett levebröd för löntagaren är en kostnad för arbetsgivaren, "arbetsköparen" som den radikala arbetarrörelsen mera korrekt kallade honom. Arbetsplatser i ett sådant samhälle är alltid ojämlika, och kommunala och statliga arbetsgivare har blivit - och ska enligt rådande politiska föreställningar vara - alltmer lika vinstdrivna privata. I mångfalden har klassrelationen arbetsköparelönearbetare delvis kommit i skymundan, vilket gör det angeläget att understryka dess betydelse här.

Å andra sidan är mångfaldens förtjänst att den visar på klassrelationens komplexitet, i flera avseenden. Klasserna är differentierade, och klassanalysen måste fördjupas. Arbetarklassen är inte bara infödda män, utan personer med olika könstillhörighet, hudfärg, födelseland, 
religion och sexualitet. Arbetsköparen är inte en enda auktoritet, utan oftast en hierarki av chefer med olika rang, och inte sällan varierande beteende. Arbetsplatser domineras inte längre av varuproduktion, lönearbetarens motpart är inte bara produktionsmedlens ägare utan också tjänstesamhällets kunder och vårdtagare, med deras krav och, inte sällan, fördomar. Anställningsförhållandena avviker alltmer från industrisamhällets och det fackligt genomorganiserade samhällets standardisering. Visstidsanställning, bemanningsföretag med osäkra kontrakt och digitala plattformsföretag som vägrar sina arbetare anställningskontrakt har förändrat arbetsmarknaden, till kapitalets fördel och arbetarnas nackdel. Allt tyder på att den utvecklingen kommer att fördjupa klyftorna mellan kapital och arbete.

Bokens fokusering på ojämlika arbetsplatser är en tankeväckande del av en senkommen kantring av samhällsvetenskapen mot ett intresse för ojämlikhet. Det är en oerhört viktig vändning, för arbetsplatserna är ett av de viktigaste centrumen för ett samhälles produktion av ojämlikhet. De mångfaldiga studierna i denna bok belyser också ojämlikhetens alla tre dimensioner.

Arbetsplatserna är troligen den viktigaste strukturella generatorn av ojämlikhet i hälsa och livslängd, av att arbetarklassens män och kvinnor måste leva ett kortare liv, ett klassgap som håller på att vidgas, i Sverige liksom i andra högt utvecklade länder.

Flera analyser i boken har visat hur arbetsförhållanden ger upphov till existentiell ojämlikhet, och hur smärtsamt detta är, att bli kränkt, diskriminerad på sin arbetsplats, som individuell person, som kvinna, som person av annat ursprung eller annan hudfärg, som person med en avvikande sexualitet.

Ens placering på arbetsplatsen avgör också ens ekonomiska resurser, ens lön. Fast för den som vill tjäna mycket pengar lönar det sig i dagens Sverige inte att arbeta, vare sig som företagare eller som löntagare. Man ska köpa och sälja fastigheter och värdepapper. Mellan 1993 och 2016 kunde man som företagare eller löntagare öka sin inkomst med 62-64 procent, men de som sysslade med kapitalaffärer ökade sina inkomster med 229 procent.

Det finns en sak som alla forskare alltid är överens om: mer forskning behövs. Vad skulle man då i första hand vilja vet mer om vad gäller 
ojämlika arbetsplatser? Två saker, tycker jag. För det första: Vad har den nyliberala privatiseringen av offentliga tjänster och new public management betytt, och vad kommer den att betyda framöver för professionellt arbete och professionella arbetsplatser, för läkare, sjuksköterskor, barnmorskor med flera inom hälso- och sjukvård, för lärare på alla nivåer av undervisning, för tjänstemän inom offentlig förvaltning? Vi har redan sett hur yrkeskunnande, yrkesetik och professionell autonomi attackeras och underordnas "verksamhetschefer" och företagsekonomiska konsulter. Nya Karolinska var avsett som ett slagskepp för den utvecklingen. Dess fiasko har kanske saktat ner processen, men knappast mer än så.

För det andra: Vad kommer digitaliseringen, automatiseringen av arbete och den digitala övervakningen av arbetsplatserna att betyda för arbetsplatsernas ojämlikhet? Arbetet kommer inte att ta slut, som en del internationella förståsigpåare påstod redan på 1980-talet, och sysselsättningen i de rika länderna har ökat mycket sedan dess. Men arbete och arbetsplatser kommer att radikalt omvandlas, och inte till arbetets fördel - om inte löntagarna kan göra hårt motstånd. 